\title{
URGENSI PENGGUNAAN MEDIA AUDIOVISUAL DALAM MENINGKATKAN MOTIVASI PEMBELAJARAN DARING DI SEKOLAH DASAR
}

\author{
Unik Hanifah Salsabila \\ Universitas Ahmad Dahlan \\ Maulida Nurus Sofia \\ Universitas Ahmad Dahlan \\ Hilda Putri Seviarica \\ Universitas Ahmad Dahlan \\ Maulida Nurul Hikmah \\ Universitas Ahmad Dahlan
}

Abstract: Audiovisual-based learning method is a learning method that combines audio and visual media or can be called visual-view media. Audiovisual media is very appropriate to be used at the elementary school level to increase student motivation from an early age. In this study, the writer has several aspects of the subject that is aimed, namely (1) knowing how the preparation process in implementing audiovisual-based learning, (2) the effect on student learning motivation, (3) knowing the effectiveness of using audiovisual-based methods in online learning. The type of research used in this research is the literature study approach (literature review). This type of literature research method is used to discuss the use of audiovisual media that is used to increase student learning motivation at the elementary school level. To collect research data, the author uses documentation techniques, namely data collection in the form of documents, data sources that are inanimate in nature, can be in the form of records, letters, assets, photos, etc.

Keywords: Audiovisual Media, Effectiveness, Learning Motivation, and Online Learning.

Abstrak: Metode pembelajaran berbasis audiovisual merupakan suatu metode pembelajaran yang menggabungkan media audio dan visual atau bisa disebut dengan media pandang-dengar. Media audiovisual ini sangat tepat digunakan ditingkat sekolah dasar untuk meningkatkan motivasi belajar siswa sejak dini. Didalam penelitian ini penulis memiliki beberapa aspek pokok bahasan yang dituju, yaitu (1) mengetahui bagaimana proses persiapan dalam menerapkan pembelajaran berbasis audiovisual, (2) pengaruh terhadap motivasi belajar siswa, (3) mengetahui keefektifan penggunaan metode berbasis audiovisual dalam pembelajaran daring. Jenis penelitian yang digunakan dalam penelitian ini adalah jenis pendekatan Studi Kepustakaan (kajian pustaka). Jenis metode penelitian kepustakaan ini digunakan untuk membahas mengenai penggunaan media audiovisual yang digunakan untuk meningkatkan motivasi belajar siswa ditingkat sekolah dasar. Untuk mengumpulkan data penelitian, penulis menggunakan teknik dokumentasi, yaitu pengumpulan data dengan berupa 
dokumen, sumber data yang sifatnya benda mati, bisa berupa rekaman, suratsurat, asset, foto dsb.

Kata Kunci: Media Audio Visual, Efektivitas, Motivasi Belajar, Pembelajaran Daring.

\section{A. PENDAHULUAN}

Merebaknya wabah pandemi Covid-19 di seluruh dunia, khususnya Indonesia memberikan dampak yang begitu terasa. Segala jenis kegiatan atau pekerjaan terhambat hingga harus dilaksanakan secara daring yang cukup dilakukan di rumah saja. Dampak ini tidak hanya dirasakan oleh mereka para pekerja saja namun dirasakan oleh semua penduduk bumi secara merata. Di dunia pendidikan juga sangat terasa dampaknya, yang membuat para pelajar dan pendidik harus melakukan aktivitasnya secara online.

Dampak akibat wabah pandemi Covid-19 pada aspek pendidikan adalah terjadinya transformasi pelaksanaan kegiatan belajar mengajar yang awalnya dilakukan secara tatap muka di kelas atau biasa disebut "luring", menjadi secara daring di rumah. Hal ini tentu menjadi perbincangan hangat karena banyak pihak yang merasa dirugikan termasuk guru. Melihat kondisi saat ini yang sedang terjadi guru dituntut agar tetap mampu menjalankan kewajibannya sebagai seorang pendidik yakni, menyampaikan ilmu kepada peserta didiknya. Biarpun pembelajaran dilaksankan secara daring, namun guru diharapkan mampu menciptakan suasana pembelajaran yang efektif dan menyenangkan seperti halnya pembelajaran secara tatap muka. Maka dari itu, seorang guru harus bisa menguasai teknologi untuk melaksanakan proses pembelajaran daring ini, agar tetap berjalan lancar. Memang tidak bisa dipungkiri satu dari sekian peserta didik mengaku lebih nyaman dengan pembelajaran tatap muka dari pada daring. Pihak guru pun sama, karena banyak dari mereka yang masih belum bisa memahami penggunaan teknologi jaman sekarang, sehingga hal ini menjadi salah satu faktor penghambat proses pembelajaran.

Pembelajaran dikatakan efektif apabila kegiatan belajar mengajar dapat mencapai tujuan sesuai pada perencanaan awal. Pembelajaran akan dikatakan efektif ketika peserta didik dapat menyerap materi pelajaran dan efisien. Problematika dunia pendidikan yaitu belum seragam antara proses pembelajaran, baik standar maupun kualitas dengan capaian pembelajaran yang diinginkan.

Menciptakan pembelajaran yang efektif dan menyenangkan selama daring menjadi tantangan tersendiri bagi seorang guru. Dengan adanya teknologi yang begitu modern diharapkan mampu mempermudah guru dalam menggunakan metode dan media apa yang sesuai dan tepat. Metode dan media yang digunakan harus mutualisme atau sama-sama menguntungkan, yakni mempermudah guru ketika menyampaikan ilmu, dan juga 
Unik Hanifah S., Maulida Nurus S., Hilda Putri S., Maulida Nurul H.

mempermudah peserta didik ketika menerima dan menyerapnya. Maka diharapkan dengan semakin berkembangnya teknologi, kegiatan pembelajaran tetap berjalan walaupun dilakukan melalui jarak jauh.

Diciptakannya teknologi bukan hanya sebagai tagline saja, namun kita harus mampu memanfaatkan dan menikmati keberadaan teknologi itu sendiri. Jika keadaan sudah seperti ini maka kita dipaksa mampu beradaptasi dengan semua hal yang serba daring dan menggunakan teknologi yang semakin canggih. Disini peran SDM diharuskan untuk melek digital sangat penting, karena apalah arti kemajuan teknologi tanpa adanya kemampuan dalam menggunakannya.

Setiap lembaga pendidikan baik dari jenjang Sekolah Dasar hingga perguruan tinggi melakukan sistem pembelajaran daring sesuai kebijakan yang dikeluarkan oleh pemerintah. Bagi kalangan mahasiswa mungkin bisa mempelajari dengan cepat, namun bagaimana dengan siswa Sekolah Dasar. Siswa-siswi sekolah dasar sangatlah dini untuk menerima kondisi saat ini, yang semuanya harus dilakukan dengan virtual. Dampak dari wabah pandemi Covid-19 sangatlah dirasakan oleh guru SD, mereka bingung mau menerapkan model pembelajaran daring yang seperti apa. Akhirnya sekolah-sekolah dasar menggunakan sistem yang berbeda dengan tingkat pendidikan yang lain. Di sekolah dasar setiap satu kali dalam seminggu orang tua harus dating ke sekolah untuk mengambil tuugas sekolah dan menyerahkan tugas yang telah diberikan minggu sebelumnya. Namun hal ini dirasa belum efektif, karena siswa sekolah dasar tidak menerima pelajaran yang langsung disampaikan oleh gurunya. Hal ini disebabkan karena kurangnya interaksi antara guru dengan siswa yang mempengaruhi efektifitas pembelajaran.

Teknologi diciptakan untuk mempermudah manusia dalam melakukan usaha dan meningkatkan kualitas ketrampilanya. Berbagai teknologi yang ada merupakan sistem yang diciptakan untuk membantu pencapaian suatu tujuan tertentu. Teknologi juga berfungsi untuk membantu memcahkan permasalahan yang ada didalam proses pembelajaran seperti sekarang ini. Mengingat perkembangan teknologi yang begitu pesat dan semakin canggih, terdapat banyak sekali media pembelajaran yang bisa digunakan selama pembelajaran daring. Salah satu media yang dirasa cukup efektif untuk digunakan siswa di tingkat sekolah dasar adalah media audiovisual, karena menggabungkan dua media sekaligus yakni audio-visual atau bisa disebut pandang-dengar. Media audiovisual ini merupakan salah satu sarana alternatif dalam melakukan pembelajaran daring. Media audiovisual diyakini dan terpercaya lebih mampu menggairahkan animo siswa di tingkat sekolah dasar, karena sifatnya sendiri yang mudah dikemas dan lebih menarik siswa untuk mengikuti dengan suasana senang. Media yang berbasis menggunakan aplikasi video ini 
juga mudah diperbaharui jika menginginkan adanya perubahan pembelajaran agar mudah dipahami. Nantinya juga akan mempermudah guru dalam proses penyampaian materi dan mengontrol suasana belajar siswa, seperti visualisasi bahan materi yang diajarkan. Sehingga proses pembelajaran daring ini lebih interaktif dan kondusif, serta siswa akan lebih termotivasi untuk tetap mengikuti pembelajaran ini walaupun dirasa sulit, tetapi menyenangkan.

\section{B. METODE}

Jenis penelitian yang digunakan dalam penelitian ini adalah jenis pendekatan Studi Kepustakaan (kajian pustaka). Jenis metode penelitian ini digunakan untuk membahas mengenai penggunaan media audiovisual yang digunakan untuk meningkatkan motivasi belajar siswa ditingkat sekolah dasar. Studi kepustakaan (Library Research) merupakan suatu studi yang digunakan dalam mengumpulkan data dan informasi dengan bantuan berbagai macam material yang ada di perpustakaan seperti dokumen, buku, majalah, kisah-kisah sejarah, dsb (Mardalis : 1999). Berdasarkan hal tersebut, maka pengumpulan data dalam penelitian ini dilakukan dengan menelaah beberapa jurnal, buku, dan dokumen-dokumen, serta sumber-sumber data atau informasi lainnya yang dianggap relevan dengan penelitian atau kajian. Sumber data yang digunakan dalam penelitian ini berupa buku, jurnal, dan situs internet yang dianggap relevan terkait topik yang telah dipilih.

Teknik pengumpulan data dalam penelitian ini adalah dokumentasi dan kajian pustaka, yakni mencari data mengenai hal-hal yang berupa catatan, buku, makalah atau artikel, jurnal, dsb (Arikiunto : 2010). Kajian pustaka merupakan cara pengumpulan data dengan mengeluarkan semua isi buku sesuai diri kita dan teknik ini khusus untuk bukubuku karangan.

Sementara itu, teknik analisis data yang digunakan dalam penelitian ini adalah metode analisis isi, yakni untuk mendapatkan inferensi yang valid dan dapat diteliti ulang berdasarkan konteksnya (Kripendoff : 1993). Dalam teknik analisis ini akan dilakukan proses memilih, membandingkan, menggabungkan, dan memilah berbagai pengertian hingga ditemukan yang relevan (Serbaguna : 2005). 
Unik Hanifah S., Maulida Nurus S., Hilda Putri S., Maulida Nurul H.

\section{HASIL DAN PEMBAHASAN}

\section{Pemilihan Media Pembelajaran}

Merebaknya kasus pandemi Covid-19 ini sangat membuat resah warga negara Indonesia, tak hanya warga Indonesia, namun seluruh penjuru dunia sangat mengkhawatirkan atas datangnya wabah ini. Apalagi sudah semakin lama kita dituntut agar selalu berhati-hati dengan virus ini, karena semakin bertambahnya hari, semakin banyaknya pula pasien Covid-19 ini, baik dari tenaga pendidik, pejabat-pejabat pemerintah, maupun dari pihak tenaga medis. Dan yang sangat memprihatinkan yaitu terkait dunia pendidikan yang semakin tidak terarah, sudah hampir 7 bulan kegiatan belajar mengajar dilakukan dirumah, karena untuk membantu memutuskan mata rantai penularan virus ini.

Baik dari lembaga formal maupun informal semuanya diliburkan atau lebih tepatnya di rumahkan. Untuk setiap sekolah diminta agar tetap melaksanakan proses pembelajaran dengan sistem pembelajaran daring atau online. Hal ini tentunya akan menjadi sebuah tantangan baru untuk lembaga pendidikan, baik dari pendidiknya maupun untuk peserta didik. Menjadi tantangan atau bahkan menjadi sebuah masalah pada siswa yang memilki keterbatasan dalam menutut ilmu, dari segi fasilitas, faktor pendukung yang biasa melakukan pembelajaran dengan tatap muka langsung dengan gurunya sekarang tidak bisa. Kini peserta didik harus berada dirumah masing-masing untuk melaksanakan sistem pembelajaran daring, yaitu dengan menggunakan personal computer (pc) atau bisa menggunakan handphone.

Banyak faktor penghambat jalannya pembelajaran daring, misalnya masalah jaringan, ekonomi, dan terutama terkait dengan materi, serta strategi dan metode pembelajarannya. Materi pembelajaran online tidak fokus pada kurikulum tetapi pada karakter adalah hal baru bagi guru dan siswa. Materi ini belum matang disusun oleh Kemendikbud sehingga guru harus mampu berimprovisiasi masing-masing. Standar pendidikan dan penilaian sangat dipengaruhi oleh kemampuan dan latar belakang guru. Strategi dan metode pembelajaran yang digunakan harus diubah, guru diminta untuk lebih berkreasi untuk membuat media pembelajaran agar tidak terlihat monoton dan membosankan. Dalam hal ini, peserta didik akan melaksanakan proses belajar dengan sistem daring yang bersifat individu, dengan mencari bahan belajar sendiri, dan mengerjakan tugas secara individu.

Media pembelajaran merupakan salah satu perantara yang digunakan dalam proses pembelajaran yang mempunyai peran penting, dan juga bagian yang tidak bisa terpisah dari metode pengajaran. Melalui media inilah proses pentransferan ilmu bisa berjalan 
dengan baik, agar bisa mencapai tujuan pembelajaran yang telah ditetapkan. Maka dari itu para pendidik harus mempelajari setiap media yang akan digunakan dalam mengefektifkan kegiatan belajar mengajar, Bretz (dalam Hujair, 2009). Perlu mengidentifikasi ciri utama dari media menjadi tiga unsur pokok, yaitu suara, visual, dan gerak, serta harus memperhatikan kondisi siswa, agar lebih mudah dalam melaksanakannya. . Jika dilihat dari jenisnya, media memiliki berbagai jenis yang berbeda-beda. Salah satu diantaranya seperti media cetak, audio, audio visual dan masih banyak lagi yang lainnya. Selama proses pembelajaran daring para pendidik $75 \%$ guru menggunakan media audiovisual untuk melakukan kegiatan belajar mengajar.

Seperti yang telah di identifikasikan oleh Bretz sebelumnya, media audio visual termasuk media yang memiliki unsur pokok seperti yang di maksudkan tersebut. Sebelum lebih lanjut menggali tentang media audiovisual, sebaiknya perlu diketahui terlebih dahulu apa itu audio dan apa itu visual. Media audio merupakan karakter media yang berupa suara. Audio dimaksudkan sebagai media penyampaian informasi dalam bentuk auditif (suara). Dari media yang di maksudkan tersebut media audio merangsang dan mengaktifkan indra pendengaran bagi responden. Salah satu contoh media berbentuk audio yaitu seperti radio, record, dan lainnya yang berunsur suara. Penyampaian informasi dengan media audio bisa dilakukan baik verbal maupun non verbal. Secara verbal dapat dituangkan dalam bentuk kata-kata ataupun lisan, kemudian non verbal dapat dituangkan dalam bentuk instrumen, musik, dan lain sebagainya.

Kemudian media visual merupakan media yang berupa gambar. Media visual digunakan dengan mengaktifkan indra penglihatan dalam menangkapnya. Jadi pada media visual ini, responden menangkap suatu informasi melalui penglihatan yang kemudian akan dicerna oleh otak dalam memahami suatu gambar. Dalam media visual sendiri terdapat media visual diam dan media visual gerak. Media visual diam yaitu dimana faktor utamanya berupa garis, simbol verbal, atau sesuatu yang berunsur gambar diam seperti sketsa, ilustrasi, foto dan lainnya. Kemudian media visual gerak yaitu dimana faktor utamanya berupa gambar dan gerak seperti slide, film bisu. Mengambil intinya, pada dasarnya media visual yaitu media yang unsur utamanya adalah gambar.

Pada kedua media tersebut dapat disimpulkan bahwa media audio visual merupakan penggabungan dari media audio dan visual. Media audio visual yaitu alat atau perantara yang bukan hanya berupa suara atau gambar saja tetapi mencangkup pada keduanya. Dengan mengkolaborasikan unsur suara dan unsur gambar, keduanya menjadi satu kesatuan yang utuh sebagai media yang biasa disebut audiovisual. Audio visual yaitu 
Unik Hanifah S., Maulida Nurus S., Hilda Putri S., Maulida Nurul H.

media yang memiliki unsur suara (audio) dan gambar (visual). Jadi, media audio visual merupakan media yang dapat di dengar sekaligu di lihat. Salah satu contoh dari media audio visual yaitu seperti video, film, televisi, dan lainnya. Media audio visual marak diterapkan di berbagai tempat, dari mulai tempat pekerjaan, bisnis, hiburan bahkan pendidikan. Terutama dalam kondisi saat ini dengan adanya pandemi covid-19 yang segala aktivitasnya dilakukan dirumah dan terhalang jarak, menjadikan teknologi semakin berguna. Seperti media audio visual sendiri yang dapat di jadikan solusi untuk mempermudah penyampaian informasi baik dalam aktivitas apapun.

Seperti yang telah kita ketahui, media audio visual juga berperan dalam pendidikan. Dalam pendidikan, media audio visual yaitu suatu alat yang menjadikan perantara antara pendidik dan peserta didik pada suatu proses pembelajaran. Media audio visual menjadi suatu alat bantu bagi pendidik dalam memudahkan melaksanakan pembelajaran terlebih dalam menyampaikan materi pembelajaran. Selain memudahkan pendidik dalam menyampaikan, pemanfaatan media audio visual juga berperan penting terhadap peserta didik. Media audio visual membantu mengaktifkan peserta didik melalui unsur pendengaran dan unsur penglihatan pada anak. Peserta didik akan menangkap informasi atau penyampaian materi dari guru melalui pendengaran dan penglihatan yang kemudian di transfer ke otak. Penggunaan media auido visual dalam pembelajaran dapat menciptakan ketertarikan pada peserta didik sehingga peserta didik lebih semangat dalam mengikuti kegiatan belajar mengajar. Media audio visual ini juga terbilang lebih menyenangkan dan mudah di mengerti oleh peserta didik.

Media audiovisual merupakan alat bantu yang berbasis suara dan gambar. Media ini mempunyai kelebihan tersendiri ketika digunakan dalam proses pembelajaran, karena bisa melihat kelangsungan proses belajar. Penggunaan media audiovisual ini terbukti lebih menarik perhatian para siswa dan mempemudah dalam menerima ilmu yang disampaikan oleh gurunya. Materi-materi pembelajaran yang disajikan dengan desaindesain menarik disertai suara penjelasan dari seorang guru itu lebih mudah untuk dipahami dan diserap oleh peserta didik. Dengan tampilan menarik disertai suara akan mengalihkan perhatian siswa agar tetap menyimak pembelajaran tersebut. Penggunaan media audiovisual diharapkan mampu menjadi solusi bagi jalannya proses pembelajaran daring ini, karena tujuan digunakannya media pembelajaran ini untuk mempermudah guru dalam menyampaikan materi atau memberi kemudahan kepada siswa dalam proses belajarnya.

Namun, pada kenyataanya setiap lembaga pendidikan belum menggunakan media pembelajaran sepenuhnya. Di sekolah dasar guru tidak menyampaikan ilmu secara 
langsung, melainkan dengan sistem yang berbeda. Setiap satu kali dalam seminggu orang tua wajib hadir disekolah untuk mengambil tugas putra-putrinya dan mengumpulkan tugas minggu lalu. Hal ini dirasa kurang efektif dilakukan, karena kebanyakan siswa merasakan jenuh dan bosan. Untuk itu pada pada penelitian ini mencoba menerapkan penggunaan media pembelajaran berbasis audiovisual di sekolah dasar.

Melihat banyaknya anak jaman sekarang sering bermain handphone, dan lebih suka melihat gambar bersuara, maka media audiovisual ini cocok diterapkan di Sekolah Dasar. Anak-anak jaman sekarang lebih tertarik untuk menyimak dan memperhatikan videovideo yang menarik dan unik. Sehingga dengan media ini, materi pembelajaran akan dikemas sedemikian rupa agar semangat-semangat belajar siswa kembali normal. Media audiovisual merupakan alat bantu pentransferan ilmu yang tepat, karena dengan desain gambar yang menarik disertai rekaman suara penjelasan itu bisa mempengaruhi daya tangkap pemahaman siswa.

Ada beberapa jenid media audiovisual yang bisa digunakan dalam pembelajaran daring, agar bisa di inovasi dalam penggunaanya, yakni Pertama, media audiovisual murni (media audiovisual gerak), maksudnya media ini menampilkan gambar dan suara yang bisa bergerak, misalnya, film dan video. Kedua, media audiovisual tidak murni (media audiovisual diam), dalam artian media ini tidak menampilkan gambar yang bergerak, contohnya seperti slide power point. Pemiliihan media pembelajaran dengan media audiovisual ini tetap harus menyesuaikan dengan tema pembelajaran, agar berjalan sesuai tujuan dari pembelajaran yang akan dicapai.

\section{Keefektifan Media Audiovisual Dalam Pembelajaran Daring}

Media audio visual dalam pendidikan digunakan sebagai alat bantu atau perantara antara pendidik dan peserta didik dalam suatu pembelajaran baik di dalam kelas maupun diluar kelas. Dalam kondisi saat ini dengan maraknya Covid-19 yang proses belajar mengajarnya dilaksanakan secara daring atau online, oleh karenanya media audiovisual tentunya sangat tepat dan penting digunakan pada masa ini. Media audiovisual terbilang sangat efektif digunakan terlebih khususnya pada pembelajaran di Sekolah Dasar. Siswa pada kalangan Sekolah Dasar merupakan kalangan anak yang terbilang dalam usia masih berkembang. Pada usia ini siswa cenderung lebih suka bermain daripada belajar, terlebih dalam keadaan sulit seperti ini dimana proses pembelajarannya pun dilakukan secara daring di rumah. Tentunya sulit pula bagi guru yang tidak dapat menyampaikan secara 
Unik Hanifah S., Maulida Nurus S., Hilda Putri S., Maulida Nurul H.

langsung materi pembelajaran. Oleh karena itu media merupakan solusi yang paling tepat dan efektif untuk mengatasi kendala tersebut.

Pada pembelajaran daring dirumah, biasanya dilakukan melalui perantara sosial media seperti WhatsApp, Google Classroom, dan lainnya. Sulit bagi kalangan anak Sekolah Dasar untuk melalui pembelajaran daring tanpa pemantauan dari orang tua. Masa anak-anak biasanya cenderung tidak memiliki alat komunikasi seperti HP, Laptop, dan lainnya untuk mengakses sosial media. Oleh karena itu, orang tua perlu dalam menyampaikan tugas apa yang di perintahkan oleh guru dan secara efektif memantau anak dalam proses pembelajaran. Anak seusia ini tidak akan efektif mengikuti proses pembelajaran tanpa pemantauan orang tua, terlebih jika proses pembelajaran dilakukan dengan hanya pemberian tugas saja. Pembelajaran yang hanya dilakukan dengan memberikan tugas, akan berdampak membosankan dan cenderung monoton bagi anak seusia siswa di tingkat Sekolah Dasar. Guru perlu menciptakan proses pembelajaran yang menarik bagi siswa dan tentunya tidak menimbulkan keterpaksaan pada siswa dalam melaksanakan pembelajaran yang hanya dilakukan di rumah atau pembelajaran daring. Seperti pada pengguaan media audiovisual ini yang terbilang dapat meningkatkan motivasi belajar siswa terutama siswa di kalangan Sekolah Dasar. Penggunaan media audio visual juga membantu guru dalam menyampaikan materi pembelajaran serta mempermudah siswa dalam memahami materi yang disampaikan tersebut. Terlebih dalam kondisi saat ini siswa akan sulit memahami jika proses pembelajaran dilakukan hanya dengan membaca secara pribadi oleh siswa tanpa adanya penjelasan atau hanya di berikan tugas saja oleh guru.

Menurut Sapto Haryoko (2009: 3) "Media audio-visual adalah media penyampai informasi yang memiliki karakteristik audio (suara) dan visual (gambar). Jenis media ini mempunyai kemampuan yang lebih baik, karena meliputi kedua karakteristik tersebut". Pemaparan tersebut menjelaskan bahwa media audiovisual yaitu sebagai wadah untuk menyampaikan materi pembelajaran dengan karakter audio yaitu suara, dan visual yaitu berupa gambar. Media ini merupakan media yang lebih baik digunakan untuk menyampaikan informasi atau materi dalam proses pembelajaran daring pada tingkat Sekolah Dasar. Penggunaan media audiovisual akan lebih efektif dan efisien dalam pembelajaran daring karena media ini berkarakter suara dan gambar seperti contohnya video, film, televisi, sesuatu yang menimbulkan suara dan lainnya yang menarik perhatian siswa. Guru dapat memberikan materi berupa video penyampaian materi atau penjelasan materi sesuai mata pelajaran yang dituju, menyarankan film atau acara televisi yang berbau pembelajaran sesuai tujuan pembelajaran, dan masih banyak lagi metode dengan 
menggunakan media audiovisual ini. Dengan demikian, terbukti bahwa pembelajaran daring pada tingkat Sekolah Dasar lebih efektif dengan digunakannya media audiovisual. Murid lebih tertarik untuk belajar, karena dengan media audiovisual ini memberikan efek berupa suara dan gambar yang membantu meningkatkan rasa keingin tahuan terhadap siswa.

Pemanfaatan media dalam pembelajaran dapat membangkitkan keinginan dan minat baru, meningkatkan motivasi dan rangsangan kegiatan belajar, dan bahkan berpengaruh secara psikologis kepada siswa (Hamalik, 1986). Seperti pendapat tersebut, penelitian ini menunjukkan bahwa pada kondisi saat ini, penggunaan media audiovisual bisa dikatakan efektif dalam meningkatkan motivasi belajar siswa. Media audiovisual membantu membangkitkan keinginan dan minat siswa pada kegiatan belajar terlebih utama pada siswa di tingkat Sekolah Dasar dengan tingkatan siswa yang masih diusia anak-anak dan masih dalam masa perkembangan. Beberapa dampak positif dari penggunaan media audiovisual, diantaranya; 1) penyampaian materi bisa lebih jelas, 2) siswa lebih terjaga dan fokus dalam menerima materi, 3) pembelajaran terlihat lebih menarik karena disertai gambar dan suara. 4) guru bisa memantau dan melihat langsung keadaan siswa dirumah, 5) bisa menambah semangat belajar siswa. Hasil dari penggunaan media audiovisual ini sangat jelas dan bisa dirasakan oleh siswa maupun pendidik.

Di dalam teknologi media merupakan sumber belajar, jadi media audiovisual sebagai sumber belajar yang membantu pendidik dalam meningkatkan pola pikir peserta didiknya. Penggunaan media pembelajaran yang sesuai dan efektif bisa meningkatkan motivasi belajar siswa, serta menjadi sumber dalam memperoleh ilmu pengetahuan. Dengan demikian bisa membantu mempermudah siswa dalam menerima dan memahami materi. Jika peserta didik tidak memiliki daya tarik atau motivasi belajar, maka proses pembelajaran daring ini gagal dilakukan. Disini penggunaan media audiovisual menjadi solusi untuk meningkatkan motivasi belajar siswa, dan membantu melawan rasa males belajarnya.

Model pembelajaran yang diterapkan untuk siswa di tingkat Sekolah Dasar menggunakan alat bantu berupa media audiovisual, yang ternyata sangat mempengaruhi hasil belajar siswa. Perbedaan pembelajaran sebelumnya yang masih dilakukan secara manual orang tua datang kesekolah, dengan menggunakan media audiovisual ini sangat terlihat jelas. Hal ini dikarenakan penggunaan media audiovisual yang sangat meningkatkan tumbuh kembangnya peserta didik. Dengan media audiovisual ini peserta 
Unik Hanifah S., Maulida Nurus S., Hilda Putri S., Maulida Nurul H.

didik dilatih dalam ketrampilannya, mengubah pola pikirnya, kemampuan dalam menyimak dan menerima materi yang disampaikan oleh guru.

Media audiovisual ini mengubah penyajian bahan ajar kepada siswa, dan hasilnya menjadi lebih lengkap dan lebih jelas untuk di terima. Selain itu, peran dan tugas guru juga tergantikan, dengan memakai media audiovisual ini peran seorang guru beralih menjadi fasilitator, yakni memberi kemudahan bagi siswanya dalam proses pembelajaran. Media audiovisual bisa berupa berbagai aplikasi video conference, slide power point bersuara, film, atau video yang berisi penjelasan materi yang disampaikan langsung oleh gurunya. Kunci keberhasilan dalam menyampaikan materi dengan media audiovisual ini adalah keberhasilan seorang guru dalam membuat atau mendesain media pembelajaran, yang sesuai dengan kondisi atau suasana peserta didiknya. Dari suksesnya guru dalam mendesain media pembelaran inilah yang akan membuat siswa merasakan senang dan tertarik untuk mengikuti pembelajaran daring ini. Penggunaan media audiovisual ini sangat memberikan kontribusi yang signifikan dalam meningkatnya motivasi belajar siswa, dan keaktifan siswa. Guru merasakan ketika dalam menyampaikan materi lebih cepat dan lebih jelas menggunakan media audiovisual ini. Adanya semangat belajar dari siswa membuat guru semakin berusaha dalam mendesain media pembelajaran, agar siswa tidak jenuh dan bosan ketika mengikuti kegiatan belajar mengajar.

Berdasarkan uraian data diatas dapat disimpulkan bahwa penggunaan media audiovisual ini sangat efektif, melihat siswa tingkat sekolah dasar ini masih dalam pertumbuhan, dan masih suka bermain-main dari pada belajar. Penggunaan media audiovisual ini sangat tepat karena basisnya yang berupa gambar dan suara, sehingga bisa mempermudah guru dalam mendesainnya. Namun disisi lain media yang didesain oleh guru harus sesuai dengan materi yang akan disampaikan, agar terlihat menarik dan lebih berkesan. Karena ketika memilih media pembelajaran yang akan digunakan juga harus disesuaikan dengan tujuan pembelajaran yang dituju. Oleh karena itu tugas guru adalah menciptakan media pembelajaran yang tidak membosankan dan siswa tertarik untuk mencermati dengan tidak ada rasa terpaksa dalam mengikutinya.

Sebenarnya tujuan utama dari penggunaan media audiovisual ini agar siswa tidak merasa jenuh atau bosan dalam belajarnya, karena sebelum menggunakan media ini siswa terlihat sangat tidak semangat dan malas untuk belajar. karena pada pembelajaran sebelumnya guru belum kreatif dalam penyampaian materi dan terhihat monoton, sehingga terkesan membosankan. Penggunaan media audiovisual juga dimaksudkan untuk meningkatkan kreativitas siswa dan membantu siswa dalam berimajinasi jauh lebih 
luas. Untuk menanggapi hal itu perlunya dorongan dari berbagai pihak, karena guru tidak bisa berjalan sendirian. Perlunya faktor pendukung dari pihak sekolah juga sangat berpengaruh di hasilnya nanti. Maka dari itu, baik dari pihak sekolah maupun orang tua harus bekerja sama, mendorong satu sama lain, agar pembelajaran daring ini tetap berjalan normal. Sudah tidak diragukan lagi penggunaan media audiovisual ini sangat tepat digunakan di masa pandemi Covid-19 ini, jika menggunakannya dengan bijaksana dan baik. Dari awal guru menggunakan media audiovisual siswa sangat antusias dalam mengikutinya. Dalam hal ini secara tidak langsung juga meningkatkan pertumbuhan dan perkembangan sikap, pengetahuan, dan ketrampilannya.

\section{Pengaruh Audiovisual Terhadap Motivasi Belajar}

Pembelajaran adalah situasi formal yang dilaksanakan secara sengaja dan di program oleh guru sebagai kewajibannya mentransformasikan ilmu kepada peserta dididknya berdasarkan kurikulum sekolah dan tujuan yang ingin dicapai. Pembelajaran juga dapat diartikan sebagai interaksi positif antara guru dengan siswa, dimana interaksi tersebut sebagai upaya agar tercapainya tujuan-tujuan yang telah dirancang. Jadi, pada hakikatnya didalam pembelajaran harus ada interaksi antara guru dengan siswa, karena pembelajaran bukan sekedar kegiatan guru menyampaikan materi saja, namun adanya penerimaan dari peserta didik berupa pemahaman. Adanya interaksi yaitu untuk mengetahui hasil apa yang dicapai selama pembelajaran.

Abdillah dalam Aunurrahman (2010:35) mengatakan bahwa belajar adalah suatu usaha sadar yang dilakukan oleh individu dalam perubahan tingkah laku baik melalui latihan dan pengalaman, yang menyangkut aspek-aspek kognitif, afektif dan psikomotor untuk memperoleh tujuan tertentu. Seseorang dikatakan belajar apabila mengalami adanya perubahan dalam dirinya. Belajar bukan hanya sekedar bertambahnya ilmu yang diperoleh, namun apakah dari ilmu yang diperoleh tersebut menjadikan acuan perubahan dalam sikap dan perilaku seseorang. Sikap dan perilaku adalah sesuatu yang dapat diamati. Maka perbedaan seseorang yang belajar dan tidak belajar bisa dilihat dari perubahan sikap dan perilaku yang ditunjukkan dalam kehidupan sehari-harinya.

Dalam upaya agar tercapainya perubahan dalam belajar dibutuhkan adanya motivasia atau dorongan. Motivasi belajar merupakan suatu dorongan yang dirasakan pada diri seorang peserta didik agar mau belajar atau melakukan suatu hal yang dapat menghasilkan perubahan. Hadirnya motivasi pada diri seseorang sangat dibutuhkan, karena ketika akan melakukan segala hal seseorang membutuhkan adanya motivasi. 
Unik Hanifah S., Maulida Nurus S., Hilda Putri S., Maulida Nurul H.

Terutama pada proses belajar, belajar merupakan kegiatan yang identik dengan kefokusan, keseriusan dalam melaksanakannya. Maka tak heran banyak orang yang tidak menyukai proses belajar. Terutama peserta didik yang masih menduduki bangku Sekolah Dasar, mereka masih sangat membutuhkan pantauan dari guru agar tetap termotivasi untuk selalu meningkatkan kualitas belajarnya.

Ada macam-macam motivasi yang dilihat dari berbagai pandangan, berikut penjelasannya:

1. Motivasi Instrinsik

Merupakan motivasi yang sudah ada dan tumbuh didalam diri seseorang atau sudah bawaan. Motivasi ini ada karena adanya kemauan dari diri sendiri bukan dari pengaruh orang lain. Contoh: ketika seseorang tidak menyukai mempelajari filsafat. Namun, ia berusaha untuk menyukainya karena ia sadar belajar filsafat akan melatih untuk berpikir kritis.

\section{Motivasi Ekstrinsik}

Merupakan motivasi yang datang karena adanya faktor pengaruh dari luar diri seseorang. Motivasi ini bukan berasal dari diri seseorang, namun sebab adanya pengaruh berupa tindakan,perkataan dari orang lain. Contoh: ketika seseorang enggan disuruh belajar. Namun ketika temannya mengajak untuk belajar bersama ia menyanggupinya karena ia merasa belajar ketika sendiri tidak menyenangkan, dan ketika belajar dilakukan bersama menimbulkan rasa semangat.

Terdapat pandangan lain yang mengatakan bahwa motivasi terdiri dari jasmaniah dan ruhaniah:

1. Motivasi Jasmaniah

Motivasi jasmaniah merupakan motivasi yang berkaitan dengan kebutuhan jasmani, seperti kebutuhan ketika seseorang lapar maka ia harus makan, ketika ia haus ia harus minum, kebutuhan bernafas, seksual, serta kebutuhan untuk istirahat jika merasa lelah secara jasmani.

2. Motivasi Ruhaniah

Motivasi ruhaniah adalah daya yang dibawa dari asal (daya spiritual). Motivasi ruhaniah berhubungan dengan hal-hal spiritual yang harus dipenuhi keberadaannya seperti beribadah, pengembangan ilmu pengetahuan, aktualisasi diri. Yang termasuk dalam motivasi ruhaniah adalah kemauan.

Sekolah marupakan tempat dimana peserta didik melangsungkan kegiatan belajar mengajar, yang terdiri dari berbagai banyaknya peserta didik. Mereka memiliki karakter dan watak yang berbeda-beda, salah satunya motivasi belajar yang dimiliki. Sudah 
menjadi tugas guru dihadapkan dengan berbagai karakter berbeda yang dimiliki peserta didik, maka dari itu peran guru cukup penting dalam meningkatkan motivasi belajar. Berikut upaya-upaya yang bisa dilakukan oleh guru guna meningkatkan motivasi belajar peserta didik:

1) Mengoptimalisasikan penerapan prinsip belajar.

Dalam proses pembelajaran guru dihadapkan dengan peserta didik dan materi bahan ajar. Maka adapun syarat penyampaian bahan ajar kepada pesert didik yang harus dikuasai oleh guru yaitu: (1) sebelum menyampaikan materi guru harus sudah mempelajari bahan materi yang akan diajarkan, (2) guru harus mampu memahami materi yang akan diajarkan, (3) guru sudah memahami porsi materi yang akan diajarkan, mana materi yang mudah,sedang, dan susah, (4)guru sudah memahami metode dan strategi apa yang akan diterapkan selama menyampaikan materi, (5) dan yang terakhir guru harus sudah memahami sifat bahan ajar yang akan disampaikan.

2) Mengoptimalisasikan unsur kedinamisan proses belajar pembelajaran.

Guru merupakan pendidik dan juga sebagai pembimbing belajar. seorang guru juga yang lebih memahami batas waktu peserta didik. Seringkali peserta didik lengah akan kesempatan belajar. Maka dari itu guru dapat mengupayakan optimalisasi unsur dinamis dalam diri peserta didik yang ada di lingkungan siswa.

3) Penggunaan media pembelajaran yang sesuai, guru harus mampu sedemikian rupa merancang media pembelajaran yang sesuai dengan keadaan peserta didik, sehingga menambah gairah belajar bagi peserta didik.

Berhasil tidaknya proses belajar mengajar sangat dipengaruhi oleh ada tidaknya motivasi belajar yang dimiliki oleh peserta didik. Kurangnya motivasi belajar tidak hanya dialami oleh peserta didik yang notabennya kurang pandai, bahkan peserta didik yang dianggap pandai pun tidak menutup kemungkinan untuk kurang dalam memiliki motivasi belajar. Apalagi siswa di bangku Sekolah Dasar, mereka masih moody ketika dihadapkan dengan belajar. Kadang-kadang merasa sangat semangat dan kadang pula mereka kurang semangat atau bahkan tidak mau belajar. Hal ini dimaklumi karena memang anak yang duduk dibangku Sekolah Dasar masih sangat labil.

Sudah menjadi tugas utama seorang guru agar mampu menumbuhkan motivasi belajar peserta didiknya. Peran guru dalam menciptakan suasana pembelajaran yang efektif, menumbuhkan motivasi belajar, tidak membosankan sangat diperlukan. Dikarenakan hampir semua peserta didik terutama di tingkat Sekolah Dasar tidak begitu tertarik dengan pembelajaran yang terlalu monoton. 
Unik Hanifah S., Maulida Nurus S., Hilda Putri S., Maulida Nurul H.

Ditambah kondisi pandemi sekarang ini yang mengharuskan pembelajaran dilakukan secara daring dari rumah. pembelajaran yang tadinya dilaksanakan secara face to face di kelas menjadi secara virtual. Menjadi tantangan tersendiri bagi seorang guru menghadapi pembelajaran daring, guru harus sepandai mungkin, sekreatif mungkin merancang pembelajaran yang apa-apa serba daring. Guru secara instan harus mampu mempergunakan berbagai jenis teknologi yang dianggap mempermudah pembelajaran daring ini.

Nyatanya merancang pembelajaran daring untuk siswa tingkat Sekolah Dasar tidak semudah ketika merancang untuk tingkat pendidikan diatasnya. Sekolah Dasar merupakan jenjang pendidikan formal level paling rendah. Pada masa ini mereka baru dikenalkan dengan ilmu pengetahuan dimana ini sebagai bekal pembentukan karakter untuk nanti kedepannya. Di tingkat Sekolah Dasar identik menyukai pembelajaran yang menarik dan menyenangkan, karena dengan cara itulah pembelajaran dikatakan mampu menumbuhkan motivasi belajar pada peserta didik. Sehingga terciptanya rasa semangat pada diri peserta didik untuk terus belajar.

Dibutuhkan media pembelajaran berbasis teknologi yang mampu menumbuhkan motivasi belajar di tingkat Sekolah Dasar. Media merupakan sebuah alat saluran komunikasi yang menghubungkan antara komunikator dengan komunikan guna memperjelas makna. Media juga bisa diartikan secara harfiah yaitu sebuah perantara. Dalam proses belajar media digunakan sebagai perangsang bagi para peserta didik agar terjadi adanya proses belajar. Melihat kondisi pembelajaran yang serba daring sekarang ini media pembelajaran berbasis teknologi sangat dibutuhkan, agar proses pembelajaran tetap terus berjalan bagaimana mestinya.

Penggunaan media pembelajaran yang baik, maka akan menciptakan hasil yang baik pula. Dalam merancang dan memilih media pembelajaran seyogyanya harus memperhatikan dampak yang terjadi kedepannya. Apakah hanya sekedar menarik, tetapi tidak efektif, atau malah menarik dan juga efektif. Seorang guru harus saling bahumembahu agar mampu mencapai tujuan menciptakan pembelajaran yang secara terus menerus. Dan mampu menumbuhkan motivasi belajar peserta didik, karena perlu diingat kembali bahwasannya tingkat kestabilan siswa yang duduk dibangku Sekolah Dasar masih sangat tinggi, sehingga mereka harus selalu dalam pantauan.

Peserta didik di tingkat Sekolah Dasar masih cenderung berpikir kongkrit atau nyata, sehingga mereka masih susah jika diberikan materi yang bersifat abstrak. Maka dari itu pemaparan materi selama pembelajaran harus divisualisasikan sehingga dianggap lebih nyata, dan peserta didik lebih mudah memahami. Ada banyak sekali media 
penunjang pelaksanaan pembelajaran yang dianggap mampu mempermudah berjalannya belajar terutama pada pembelajaran daring sekarang ini. Media yang sering digunakan oleh guru biasanya adalah media berupa visual dan media audiovisual, karena media ini merupakan komponen media yang cocok dan praktis diterapkan pada pembelajaran daring sekarang ini

1. Media visual

Media visual adalah media yang paling familiar dan sering digunakan oleh guru sebagai alat membantu proses selama pembelajaran. Media ini melibatkan indra penglihatan, serta dapat membantu dalam memperlancar pemahaman dan juga mampu mempertajam ingatan. Media visual juga mampu menumbuhkan minat belajar siswa karena dapat memberikan pemahaman yang kongkrit. Sesuai dengan kondisi peserta didik di tingkat Sekolah Dasar yang memang kurang berminat jika harus dihadapkan dengan pembelajaran yang bersifat abstrak.

2. Media audiovisual

Media audiovisual adalah media yang memiliki unsur suara dan gambar. Media ini memiliki kemampuan lebih baik sebagai penunjang proses pembalajarn daring, karena tidak hanya melibatkan indra penglihatan saja, namun juga melibatkan indra pendengar sekaligus. Contoh: penyajian video, berbagai film, ppt slide suara, VCD dan lain sebagainya.

Semua jenis media pembelajaran yang ada sudah sangat baik dan mampu membantu, memperlancar jalannya kegiatan belajar mengajar, terutama pembelajaran daring. Namun sebagai guru harus cerdas dalam memilah dan memilih jenis media apa yang sesuai dengan kondisi peserta didik. Bukan hanya melihat dari aspek pribadi namun guru harus lebih memperhatikan dari aspek peserta didik.

Media audiovisual dianggap lebih sesuai, efektif, efisien jika diterapkan untuk pembelajaran pada tingkat Sekolah Dasar, karena lebih menumbuhkan semangat belajar biarpun pembelajaran dilaksanakan secara daring. Media audiovisual dirasa lebih menarik sebab tidak hanya mengandung unsur auditif namun juga mengandung visual. Penggunaan media audiovisual sangat efektif sebagai pemanfaatan alat indera.dalam arti peserta didik dapat mengikuti pembelajaran dengan melibatkan lebih dari satu indera. Media audiovisual dapat dibagi:

a. Audiovisual diam, merupakan media yang hanya menampilkan suara dan gambar, namun tidak bergerak, contoh: film bingkai (sounds slides),film rangkai suara, dan cetak suara 
Unik Hanifah S., Maulida Nurus S., Hilda Putri S., Maulida Nurul H.

b. Audiovisual gerak, merupakan media yang menampilkan unsur suara serta gambar secara bergerak. Contoh: film suara, video-cassete

Media audiovisual memiliki banyak macam, dari berbagai macam inilah sangat membantu guru dan peserta didik untuk memahami materi-materi pembelajaran. Berikut macamnya:

1. Film

Film merupakan rangkaian berbagai gambar yang di proyeksikan ke layar sehingga timbul adanya gerakan secara normal. Film menjadikan rangkaian gambar yang tadinya diam menjadi berkesan lebih hidup dan nyata karena adanya pergerakan yang ditimbulkan. Film merupakan salah satu media yang menyajikan audio, visual dan gerak. Sehingga mampu memberikan kesan yang mendalam (impresif) dan memiliki daya tarik serta bersifat menyenangkan (atraktif). Dalam proses pembelajaran film disajikan sebagai media mengajar, diperuntukan agar peserta didik dapat mengambil pesan dari alur cerita sesuai tema dan subjek pembelajaran. Penggunaan media film dalam penyampaian materi lebih menarik perhatian peserta didik, karena mereka lebih mudah memahami dan mengambil pesan dan kesan yang terkandung di dalam film yang ditonton. Jenis film yang bisa dipilih sesuai keinginan pun juga memudahkan guru agar menambah motivasi belajar peserta didik.

Penggunaan media film sebagai penyampaian materi memiliki kelebihan yang bisa sama-sama dirasakan: film sangat efektif untuk menerangkan sebuah proses, efisien tempat dan waktu, dirasa lebih realistis, serta dapat dilihat secara berulang bahkan bisa dijeda sesuai keinginan dan kebutuhan. Film juga lebih memberikan kesan mendalam yang dapat memengaruhi sikap dan perilaku pserta didik yang menonton. Tidak hanya itu film mampu memberikan hiburan tersendiri bagi peserta didik sehingga sangat cocok untuk menghilangkan rasa bosan ketika belajar.

Ketika ada kelebihan maka ada kekurangan yang mengiringi, penggunaan media film untuk penyampaian materi juga memiliki kekurangan didalamnya. Harga produksi yang dibilang cukup mahal, pembuatan film yang juga memakan banyak waktu dan tenaga, memerlukan ruangan yang di desain gelap, serta pengoperasian pun harus dilakukan oleh orang yang cakap akan dunia teknologi.

Dalam dunia pendidikan dan pembelajaran film berguna untuk:

a. Membantu dalam mengembangkan pikiran serta pendapat peserta didik.

b. Memperkuat daya ingat pada materi yang disampaikan. Sehingga segala materi yang disampaikan oleh guru dengan mudah tersimpan dan teringat oleh peserta didik. 
c. Menambah minat serta motivasi belajar peserta didik, karena penyampaian film sendiri yang lebih bisa memberi kesan menarik pada peserta didik, membuat peserta didik lebih suka menonton film sebagai media belajar.

d. Sangat membantu memperjelas sesuatu yang masih abstrak, film lebih mampu menjelaskan suatu materi yang dirasa masih abstrak dengan tampilan gambaran yang nyata . sehingga peserta didik tidak hanya berkhayal namun juga mampu merelevansikan dengan kehidupan nyata.

Jenis-jenis film pun sangat bermacam-macam, sehingga mempermudah guru untuk memilih mana yang dirasa cocok diterapkan jenjang Sekolah Dasar. Pemilihan film yang sesuai maka akan menambah motivasi belajar peserta didik. Namun guru juga harus mampu menyesuaikan dengan materi dan subjek yang akan disampaikan.

\section{Video}

Penyampaian materi melalui video sudah sangat familiar karena sering digunakan oleh guru. Video merupakan salah satu media berjenis audiovisual karena mampu menampilkan gambar, suara, dan juga gerak. Media ini dianggap efektif digunakan untuk menyajikan berbagai topik pembelajaran yang sulit jika harus disampaikan secara oral. Video mampu menhadirkan objek-objek yang dirasa mustahil jika harus ditampilkan secara nyata. Video adalah media yang mampu mengemas segala kejadian secara praktis namiun tetap mampu menghadirkan suasana yang nyata. Contohnya; ketika guru harus menyampaikan materi tentang thowaf, dimana harus menampilkan orang sedang mengelilingi ka'bah. Tidak mungkin guru menyampaikan materi dengan menghadirkan ka'bah secara nyata, walaupun dilakukan secara visual juga dibutuhkan banyak waktu. Melalui video materi bisa disampaikan secara efisien tempat dan waktu. Guru juga dapat mempersiapkan video penyampaian materi jauh-jauh hari untuk melalukan proses persiapan hingga jadwal pembelajaran tiba. Dalam kata lain guru bisa lebih totalitas dalam penyampaian materi.

Video dapat menyajikan pesan secara obyek, kejadian, ataupun informasi nyata, tetapi bisa juga bersifat fiktif belaka. Pada pembelajaran daring, media video lebih mampu menarik perhatian peserta didik, serta menumbuhkan motivasi belajar. Karena tampilannya yang memang lebih jelas membuat peserta didik khususnya di tingkat Sekolah Dasar lebih merasa dipermudah. Sekarang ini ada banyak sekali jenis-jenis video yang dikemas secara praktis, seperti VCD (video compact disk). Penggunaan media video selama pembelajaran daring sangat cocok untuk untuk diterapkan di Sekolah Dasar. Oleh 
Unik Hanifah S., Maulida Nurus S., Hilda Putri S., Maulida Nurul H.

karena itu, guru harus mampu memanfaatkan secara maksimal agar motivasi belajar peserta didik tetap terkendali

Dari berbagai media audiovisual yang sudah sebutkan dan dipaparkan oleh penulis maka dapat disimpulkan bahwasannya media audiovisual merupakan media yang melibatkan indra penglihatan dan indra pendengar sekaligus. Media audiovisual dirasa lebih efektif dan mampu menumbuhakn motivasi belajar terutama selama pembelajaran daring. Dikarenakan kondisi saat pembelajaran daring berbeda dengan pembelajaran tatap muka di kelas, memerlukan lebih banyak kreativitas guru dalam merancang dan menerapkan media yang digunakan selama pembelajaran. Di tingkat Sekolah Dasar merupakan tingkatan dimana mereka masih moody ketika belajar, sangat dibutuhkan berbagai upaya yang harus dilakukan guru selama pembelajaran.

\section{KESIMPULAN}

Berdasarkan hasil pembahasan diatas dapat kita simpulkan bahwa penggunaan media audiovisual selama pembelajaran daring di tingkat sekolah dasar sangat efektif. Media audiovisual sangat mempengaruhi motivasi belajar siswa karena karakteristiknya yang berbasis gambar dan suara, sehingga mempermudah siswa dalam menerima materi. Dalam proses pembelajaran kedudukan motivasi belajar sangatlah penting, maka sudah menjadi keharusan bagi guru untuk terus melakukan upaya agar motivasi belajar tetap tumbuh pada diri peserta didik. Munculnya motivasi belajar bukan hanya dari diri peserta dididk sendiri, melainkan terdapat faktor-faktor yang memengaruhi. Salah satunya guru, peran guru penting dalam memotivasi belajar peserta didik. Terutama pada pembelajaran yang serba daring sekarang ini, guru dituntut agar lebih cerdas, dan kreatif untuk menciptakan pembelajaran yang tetap efektif dan menimbulkan motivasi belajar.

Pembelajaran daring tak terlepas dari pemanfaatan kemajuan teknologi, ada berbagai media pembelajaran berbasis teknologi yang bisa digunakan sesuai kebutuhan. Namun tidak semua media yang ada mampu menyesuaikan kondisi peserta didik. Terutama jika harus diterapkan peserta didik tingkat Sekolah Dasar, mereka menyukai pembelajaran yang bersifat kongkrit, dan menarik. Maka penggunaan media audiovisual menjadi pilihan yang dianggap efektif dan mampu menumbuhkan motivasi belajar. Media audiovisual merupakan media yang melibatkan indra penglihatan dan pendengaran sekaligus dalam arti mampu menampilkan gambar dan suara, contoh dari media audiovisual; video, film, televisi, dll. 


\section{DAFTAR PUSTAKA}

Nurseto, Tejo. (2011). Membuat Media Pembelajaran yang Menarik. Jurnal Ekonomi \& Pendidikan. 8(1)

Lestari, A T, dkk. (2017). Keefektifan Media Audi Visual sebagai Kreativitas Guru Sekolah Dasar dalam Menumbuhkan Keterampilan Menulis Puisi Siswa. Jurnal Pendidikan dan Kebudayaan. 7(3): 214-225

Muhson, Ali. (2010). Pengembangan Media Pembelajaran Berbasis Teknologi Informasi. Jurnal Pendidikan Akutansi Indonesia. VIII(2): 1-10

Kustandi, Cecep, Darmawan D. (2020). Pengembangan Media Pembelajaran: Konsep \& Aplikasi Pengembangan Media Pembelajaran Bagi Pendidik di Sekolah dan Masyarakat. Jakarta: Kencana

Hamid, M A, dkk. (2020). Media Pembelajan. Yayasan Kita Menulis

Jaelani, Ahmad, dkk. (2020). Penggunaan Media Online dalam Proses Kegiatan Belajar Mengajar PAI dimasa Pandemi Covid-19. Jurnal Ikatan Alumni PGSD UNARS. $8(1)$

Emda, Amna. (2017). Kedudukan Motivasi Belajar Siswa dalam Pembelajaran. Lantanida Journal. 5(2)

Huda, M.J. (2018). Keefektifan Media Audio Visual Terhadap Motivasi Belajar Siswa di Sekolah. Jurnal Pendidikan. 2(4)

Irawan, V.W.E. (2019). Peranan Kecerdasan Spiritual dalam Meningkatkaan Motivasi Belajar Siswa. Jurnal Ilmu Pendidikan dan Pembelajaran. 1(1): 33-47

Oktadinata, Sandra. (2011). Pengaruh Penggunaan Media Audio Visual Terhadap Peningkatan Motivasi dan Hasil Belajar Siswa Kelas XI pada Standar Kompetensi Memperbaiki Sistem Starter dan Pengisian di SMK Muhammadiyah 4 Klaten Tengah. Fakultas Teknik: Universitas Negeri Yogyakarta. Yogyakarta.

Yusmarwati. (2018). Efektifitas Penggunaannn Media Audio Visual Terhadap Motivasi dan Hasil Belajar Mengidentifikasi Unsur-unsur Cerita Anak di Kelas V SD Negeri 018 Kubang Jaya Kecamatan Siak Hulu. Jurnal Pendidikan dan Pengajaran. 2(3): 387-394

Bambang, Lestari, dkk. (2015). Penerapan Pembelajaran Media Audio-Visual untuk Meningkatkan Motivasi dan Hasil Belajar Pada Mata Pelajaran Biologi di Kelas VIII A SMP GKST Imanuel Palu. Jurnal Sains dan Teknologi. 4(1): 23-28

Ibrahim, Muhammad. (2018). Pemanfaatan Media Audio Visual dalam Meningkatkan Motivasi Belajar Peserta Didik Paket C. Jurnal Ilmu Pendidikan dan Pengajaran. $5(1)$

Nina, I.A. (2014). Pemanfaatan Media Audio Visual sebagai Sumber Pembelajaran Sejarah. Indonesian Journal of History Education. 3(1): 40-45 
Unik Hanifah S., Maulida Nurus S., Hilda Putri S., Maulida Nurul H.

Bastomi, M.R, Hartoto, Setiyo. (2018). Pengaruh Penerapan Media Audio Visual Terhadap Hasil Belajar Renang Gaya Dada. Jurnal Pendidikan Olahraga dan Kesehatan. 06(01): 5-9

Gani, I.N.F, Rais, Jamaluddin, P. (2017). Penggunaan Media Audiovisual untuk Meningkatkan Hasil Belajar Siswa dalam Pelajaran Membiakan Tanaman dengan Biji Jurusan Agribisnis Pembibitan dan Kultur Jaringan Kelas X di SMK Negeri 4 Jeneponto. Jurnal Teknologi Pertanian. 3: 49-57

Fujiyanto, Ahmad, dkk. (2016). Penggunaan Media Audiovisual untuk Meningkatkan Hasil Belajar Siswa Pada Materi Hubungan Antar Makhluk Hidup. Jurnal Pena Ilmiah. 1(1): 841-850

Suprihatin. (2017). Penerapan Media Audio Visual Dalam Meningkatkan Keterampilan Menulis Puisi Siswa Kelas VIII SMP Negeri 13 Palembang. Jurnal Bindo Sastra. 1(1): 45-51

Maryamah, Effendy, M.H. (2019). Penerapan Media Audio Visual dalam Pembelajaran Keterampilan Membaca Cepat pada Siswa Kelas XI di Ma Al-FalahTlanaka Pemeksaan. Jurnal Pendidikan Bahasa dan Sastra Indoneia. 1(1): 1-9

Lestari, Arum. (2017). Keefektifan Media Audio Visual sebagai Kreativitas Guru Sekolah Dasar dalam Menumbuhkan Ketrampilan menulis Puisi Siswa. Jurnal Pendidikan dan Kebudayaan. 7(3): 214-225. https://doi.org/10.24246/j.scholaria.2017.v7.i3.p214-225 